\title{
PSYCFE.
}

\section{NOTES ON THE WINTER INSECT FAUNA OF VIGO COUNTY, INDIANA.- III.}

BY W. S. BLATCHLEY, INDIANAPOLIS, IND.

\section{HEMIPTERA-HETEROPTERA.}

(CONTINUED.)

\section{Capsidae.}

39, Lygus pratensis Linn. Very common in both summer and winter. In the latter season it is found in numbers beneath and between the radical leaves of every mullein plant. The species varies greatly with the season, and the winter form may be flavo-maculatus Prov.

40, Callicapsus histrio Reut. A southern insect, but two specimens of which have been taken in Indiana. They were found beneath the bark of a black oak (2uercus coccinea tinctoria Gray) log which lay on the side of a high sandy hill near the Wabash River. Feb 19, 1893.

\section{Acanthindae.}

4I, Anthocoris musculus Say. An uncommon species in winter, when it is found beneath the bark of willow trees.

42, Acanthia lectularia Linn. The "festive bed-bug" - found in all stages in its usual abiding places.
Tingitidae.

43, Piesma cinerea Say. Common; gregarious. Hibernates beneath the bark near the bases of red and black oaks, and beneath logs on sandy hillsides.

44, Corythuca ciliata Say. Frequent in winter beneath the loose bark of the sycamore (Platanus occidentalis L.) and beneath $\log$ s and rubbish near them. Gregarious.

\section{Aradidae.}

45, Aradus robustus Uhler. Scarce. Hibenates beneath the bark of red and black oaks. Feb. 15, 1891.

46, Aradus similis Say. Rare. Two mature specimens were taken from beneath an oak $\log$, March 16 , I 89r. The species, therefore, certainly hibernates either as nymph or imago.

47, Aradus crenatus Say. Winters in all stages beneath logs and chunks whose sides are deeply buried in sand and mold. Our largest species of the genus.

48, Aradus americanus H. Schf. Rare. Two were taken from beneath a log on a sandy hillside, Feb. 11, I892. This species is not listed in 
Uhler's catalogue, but it was so named for me by Mr. Uhler.

49, Aradus sp.? Rare. One imago and two nymphs of this unidentified species were taken from beneath some oak chips on a sandy hillside, Jan. I, I 893 .

5o, Brachyrhynchus lobatus Say. Rare. One specimen from beneath the bark of an elm log, Dec. 16, 1892.

$5^{\mathrm{I}}$, Brachyrhynchus simplex Uhler. Our most common member of the family. Winters in all stages beneath the bark of red oak logs. Gregarious.

\section{Nabidae.}

52, Coriscus ferus Linn. A common winter resident beneath logs and leaves of mullein along roadsides and the borders of dry upland fields.

53, Coriscus punctipes Reut. Scarce in winter. Several were found with ferus beneath chunks in the sandy bed of the old Wabash and Erie Canal, Jan. I, I893.

54, Coriscus sp.? Rare. Two were taken from beneath a log partly buried in the sand near the border of a pond, on Jan. I, I 893. Uhler returned them marked, " new to me."

\section{Reduviddae.}

55, Sirthenea carinata Fab. Another southern form but three of which have been taken by myself in this State. One of these was found beneath a $\log$ partly buried in low wet ground on Feb. 21, 1892. The others in similar localities in April.
56, Melanolestes picipes H. Schf. Rather common in winter, singly or in pairs, in dry upland woods beneath logs whose sides are deeply buried in leaves and mold. Experience has taught me that this "bug" can inflict a severe wound with its beak when handled carelessly.

57, Melanolestes abdominalis $\mathrm{H}$. Schf. Much less common than the preceding. Hibernates in similar places. Dec. I8-Jan. I I.

58, Opsicoetus personatus Linn. The nymphs only, with body very thin and covered with an accumulation of dust, have been taken in houses in winter. They reach maturity about June to when they fly into houses in the early evening, attracted by the lights.

59, Pygolampis pectoralis Say. Quite frequent in winter both as nymphs and adults. Found singly or in pairs beneath chunks and boards, along roadsides and borders of upland woods.

6o, Oncerotrachelus acuminatus Say. Common. Often as many as 50 are found hibernating beneath one chunk or log; preferably those of damp localities.

\section{Emesidat.}

6I, Barce annulipes Stål. Uncommon. Taken on three different occasions in winter from beneath pieces of rails along the border of a cultivated upland field. A pair were found in copulation, Nov. 20,1892 . 
Hydrobatidae.

62, Hydrotrechus remigus Say. Frequent. Hibernates beneath logs and piles of drift along the border of streams. Sometimes seen warm days in latter part of February on the surface of the water.

63, Limnotrechus marginatus Say. Frequent. All that I have found in winter were beneath logs on hillsides, 200 yards or more from water.

64, Limnoporus rufoscutellatus Lat. This species, abundant on the lakes of northern Indiana, has been found only in small numbers on a large pond in Vigo Co. Two living specimens were found beneath a pile of dirift near the border of the pond on Jan. I, I893.

The species of Zaitha, Belostoma, Ranatra, and, perhaps, Notonecta, presumably pass the winter as nymphs, inhabiting the mud in the bottoms of ponds and streams; but as I have taken none of them at that season they are not incorporated with the above list of winter Heteroptera, which includes only such species as I have actually found hibernating.

\section{SOME HABITS OF FORMICA OBSCURIPES FOREL, WITH NOTES ON SOME INSECTS FOUND ASSOCIATED WITH IT.}

\section{BY GEORGE B. KING, LAWRENCE, MASS.}

It is generally believed and is also stated by the majority of writers upon the habits of ants, that in such climates as we have in our northern States and Canada, the ants just before the ground begins to freeze go down into their burrows below the freezing point, and remain there until the approach of spring, when they ascend again, attend to their accustomed avocations, and repair their nests.

To satisfy myself as to whether or not this were true, I last year located and marked three of the mounds in which this ant lives; they were several miles apart. On November 25 at 3 P. M. I went with my son to nest no. I. The temperature of the air was $38^{\circ}$, the snow which had fallen on the morning previous had nearly disappeared, and it was gradually growing colder. We removed some of the earth from the top of the nest, and at the depth of six inches we found plenty of ants. They were in a sluggish condition and apparently asleep and when disturbed could barely move about. We continued digging down to the depth of two and one-half feet and found ants huddled together in little piles all through the nest. I took the temperature at this depth, $33^{\circ} \mathrm{F}$. The ground froze the following night and remained frozen all winter. We collected $\mathrm{I} 77$ of the ants, and brought them home to look for winter parasites on ants. I found 8 

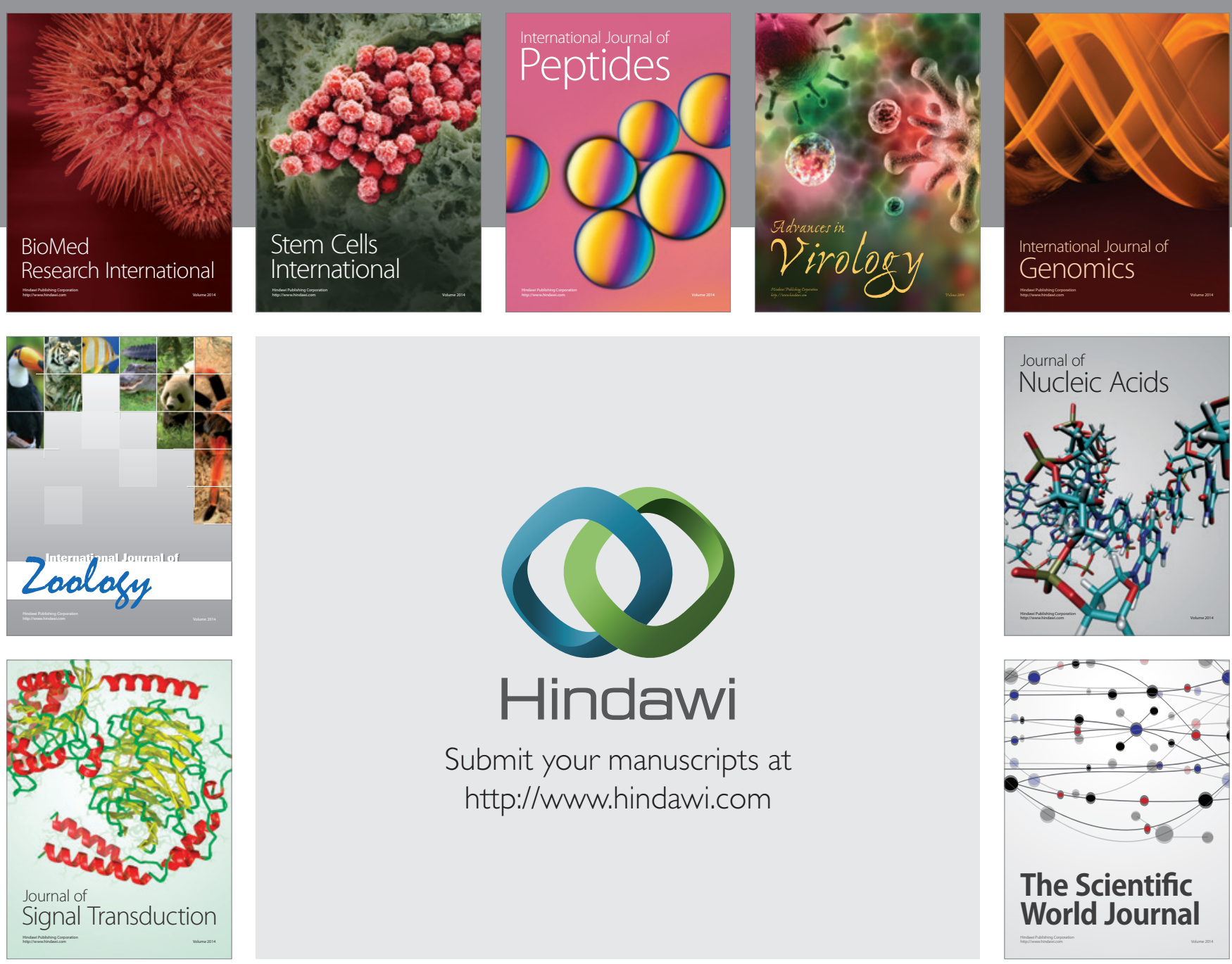

Submit your manuscripts at

http://www.hindawi.com
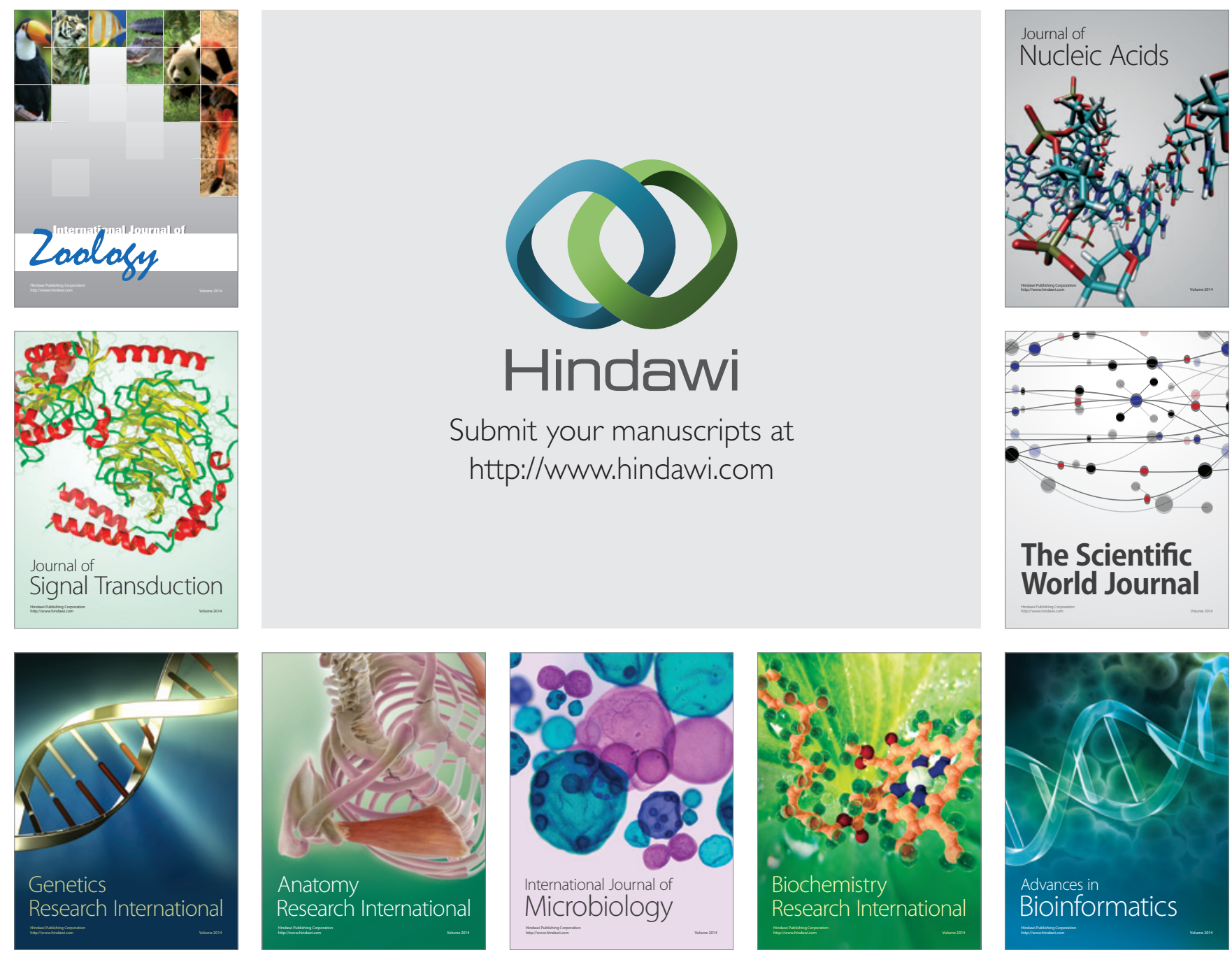

The Scientific World Journal
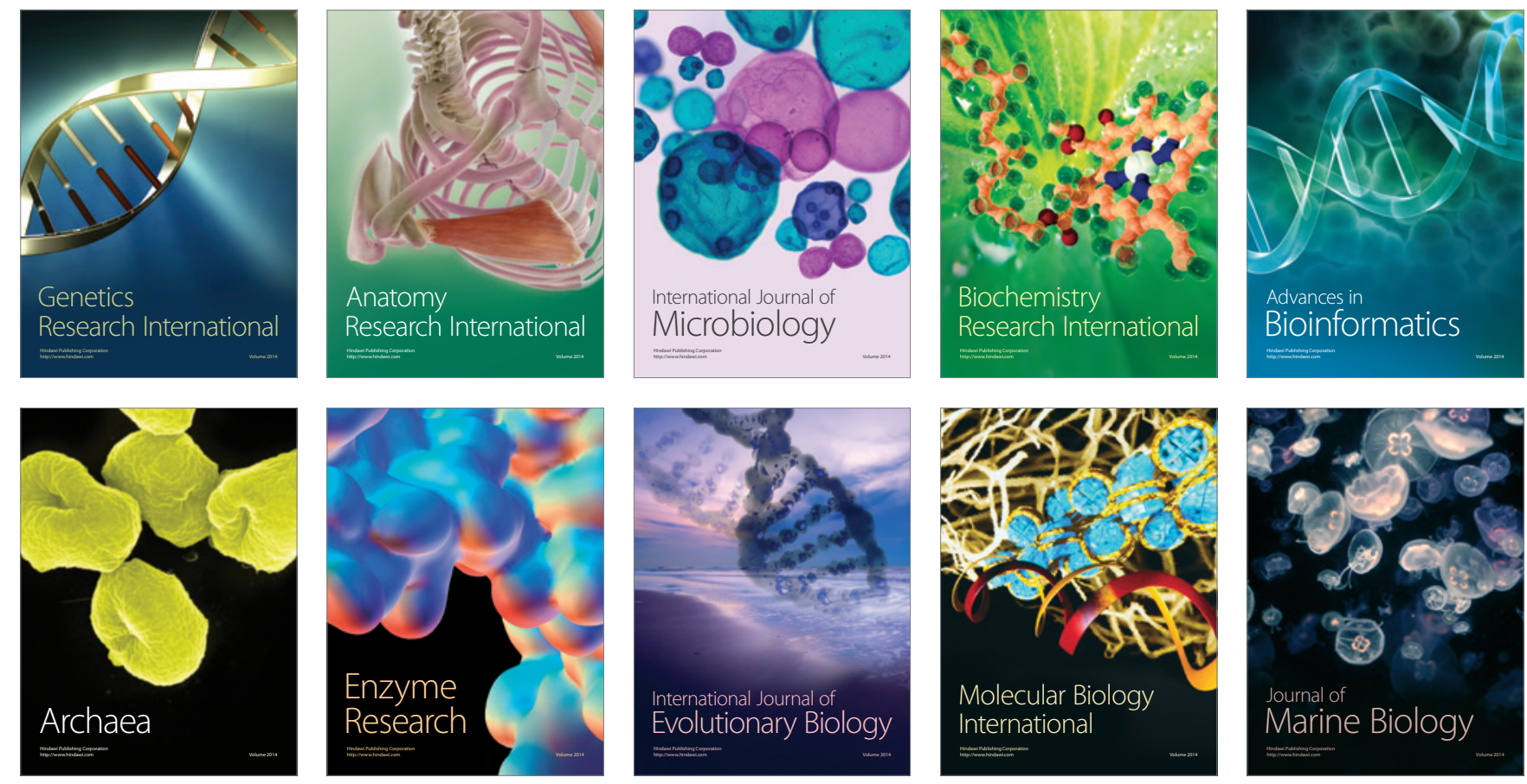